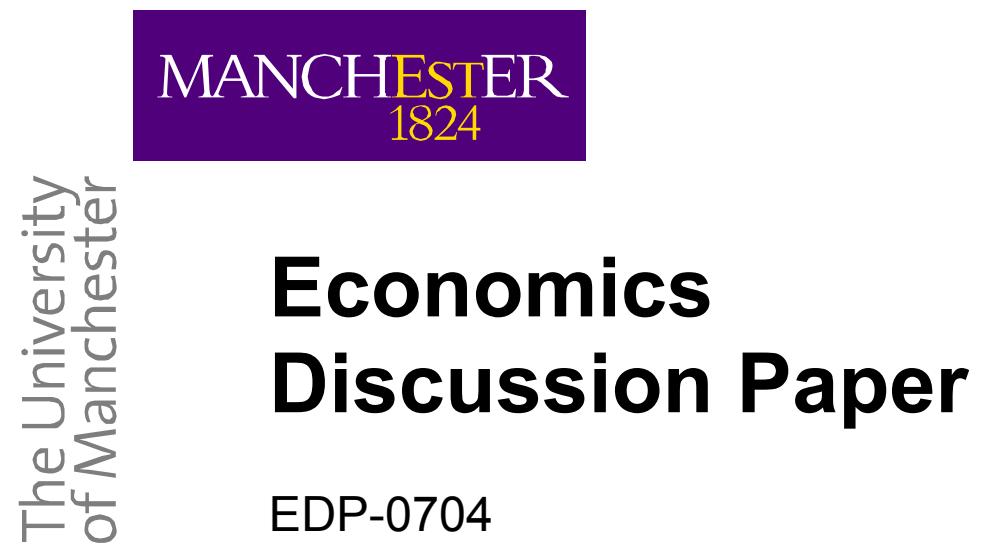

\title{
Firm Performance and Privatization in Ukraine
}

By Galyna Grygorenko and Stefan Lutz

February 2007

Download paper from:

http://www.socialsciences.manchester.ac.uk/economics/research/discuss.htm 


\title{
Firm Performance and Privatization in Ukraine*
}

\author{
Galyna Grygorenko** and Stefan Lutz ${ }^{* * *}$
}

13 February 2007

Investigating the effects of privatization in transition countries is the focus of a large body of current research. Generally, privatization stimulates private sector development, attracts foreign direct investment, fosters competition and contributes to the formation of stock markets. In addition, privatization may improve individual enterprises' performance. This paper investigates the impact of privatization on Ukrainian firms' productivity. The empirical research is based on a sample of 466 Ukrainian joint-stock enterprises for the period of 1997 1999. Estimation results indicate that privatization positively influences labor productivity, sales and profitability, but also that these effects diminish over time.

JEL classification: L22, L60, M10

Keywords: Ukraine, manufacturing firms, ownership, profitability

\footnotetext{
* The views expressed in this paper are those of the authors and do not necessarily reflect those of the institutions they are affiliated with. The authors acknowledge the hospitality of the National University "Kiev-Mohyla Academy” and financial support by the Kyiv EERC Program in Economics and by the Institute of Economic Research and Policy Consulting (IERPC), Kiev. They also would like to thank Charles Steele and Roy Gardner for helpful comments and suggestions. The usual disclaimer applies.

** Address: Galyna Grygorenko, McCann Erickson, 10 Dymytrova vul., $4^{\text {th }}$ Floor, Kyiv, Ukraine, Email: galyna_grygorenko@mccann.kiev.ua.

*** Correspondence: Stefan Lutz, NERA Economic Consulting, Konrad-Adenauer-Strasse 17, 60313 Frankfurt, Germany, Stefan.lutz@nera.com, T. +49-69-710-447-511. Lutz also holds Research Fellowships at the University of Bonn and at the University of Manchester.
} 


\section{Introduction}

During the last decade, governments in countries of Eastern and Central Europe, as well as in CIS countries, have launched large-scale privatization programs. Privatization policy implies reducing the government's role in regulation of economic processes, and decline in the share of state property in the country's national wealth. This policy is considered to be one of the most important elements of transition from state to market economy (Sheshinski and Lopez-Calva, 1999; Megginson and Netter, 2001). Most policy advisors and academic economists suggest that privatization is the corner stone of the structural reforms, because it stimulates private sector development in the country, attracts FDI inflows, fosters competition, promotes liberalization of trade, favors the development of capital and product markets, and contributes to the development of stock markets and corporate governance systems. Specifically, it is also argued that privatization significantly affects operating and financial performance of enterprises (Vickers and Yarrow, 1991; Megginson and Netter, 2001; Djankov and Murrel, 2002, 2000).

However, the empirical evidence on privatization in transition countries is quite contradictory. While some research presents positive results of privatization (mainly in countries of Central Europe and the Baltic States), there exist other studies reporting weak correlation between privatization and improvements in firm performance. ${ }^{1}$ For Ukraine, a large transitional country, the evidence on the effects of privatization so far is rather mixed. Along with the launching of

\footnotetext{
${ }^{1}$ Studies finding beneficial effects of privatization in transition countries include Brown and Earle (2004), Earle and Estrin (2003), Claessens and Djankov (1998, 1999) and Megginson et. al. (1994). Note that Brown and Earle (2004) find small positive effects for Ukraine, but negative effects for Russia. Studies that find no clear evidence for positive effects include Nellis (1999), Frydman, et. al. (1998), Black, et. al. (2000). Megginson and Netter (2001) present a review of both theoretical and empirical literature. Djankov and Murell (2002) contain an overview of empirical studies. Megginson (2005) presents an up-to-date global summary on privatization results.
} 
the stabilization program in the country in the early 1990s, the Ukrainian government has made great efforts towards privatization (Paskhaver, 2000; Chechetov, 2000). Despite the fact that the relevant legislation ${ }^{2}$ was adopted with ambitious privatization goals, the privatization process has not been as speedy and successful as it was expected by many policy makers (IMF, 1999; EBRD, 1999). The reasons for that are quite common in transitional countries of the former USSR (World Bank, 1999). Complicated implementation procedures, inherited nonefficient structure of industries, enterprises accustomed to a state order system, weak incentives for profit maximizing behavior, non-transparency of the legal and business environment, and excessive bureaucracy in the highest bodies of power have all contributed to continued blockage of progress in privatization. Privatization may not be successful if ownership is largely domestic and dispersed rather than concentrated in the hands of foreign enterprises or banks (Pivovarsky, 2003). Nevertheless, there is some evidence for positive effects of privatization. $^{3}$

Therefore, we would like to further investigate the impact of ownership, specifically privatization, on operating efficiency of Ukrainian enterprises. Our data consists of a sample of 466 joint-stock companies over a three-year period starting from 1997. The research focuses on joint-stock companies only, but we believe that this will not distort our results in a significant way, since the vast majority of privatized firms in Ukraine are collectively owned enterprises ${ }^{4}$.

\footnotetext{
2 The Law of Ukraine “On Privatization of the State Property”, No. 2613-12, 4 March 1992, the Law of Ukraine “On Privatization Certificates”, No. 2713-12, 6 March 1992. Presidential Decree “On Expedient Measures to Accelerate Privatization in Ukraine”, No. 1626; December, 29, 1999.

${ }^{3}$ See, for example, Grygorenko (2001).

${ }^{4}$ UEPLAC (2001) defines as ‘enterprises of collective ownership’ all classical joint-stock companies (closed or open) as well as enterprises bought by workers (after initially being leased with the right of buy-out). Firms of this group generated about 70 percent of total output of Ukraine in the year 2000 (Derzhkomstat, 2000).
} 
The remainder of the paper is organized as follows. Section 2 gives an overview of the Ukrainian privatization process. In Section 3, the data and model specification are presented. Section 4 contains the regression results and concludes.

\section{Ukrainian Background}

The process of privatization in Ukraine has begun in 1992, when the Ukrainian Parliament approved the relevant legislation and the first State Privatization Program ${ }^{5}$. At that time, privatization was the major item on the agenda of Ukrainian reformers — the first step in the process of transition to a market economy (Yekhanurov, 2000). Political reasons were the primary determinants shaping privatization strategy. Low popularity of reforms among Ukrainians, the dominance of communist bureaucracy in the highest bodies of power, lack of private capital — all these seemed to contribute to the impossibility of "big-bang" reforms. A mass privatization approach was chosen in order to provide the fastest transfer of ownership from public to private hands, and to guarantee the irreversibility of transition reforms (Roland, 2000). In the meantime, there is evidence that chosen privatization methods determined the resulting ownership structure of Ukrainian firms (Pivovarsky, 2003). Ownership structure, in turn, has a decisive influence on Ukrainian firms’ performance.

The Ukrainian voucher privatization was carried out with substantial distortions, which caused some negative impacts for the whole privatization process. The idea of a "fair" distribution of property rights among all citizens of Ukraine obviously could not help in implementing one of the primary goals of privatization - improvement of enterprise efficiency. A diluted ownership structure which was formed as a result of mass privatization (Akimova and Schwödiauer, 2000; Yekhanurov, 2000) led to deteriorative effects on

\footnotetext{
${ }^{5}$ Verkhovna Rada. The State Privatization Program for 1992. No. 2545-XII, July, 7, 1992.
} 
monitoring and incentives of managers. Employees and managers of enterprises were granted advantages in the privatization process, and this distortion led to the emergence of so-called “insider"-controlled firms ${ }^{6}$ (Yekhanurov, 2000). Consequently, managers have little incentive to launch efficiency enhancing restructuring programs, fearing that this process will lead to lay-offs of workers (also shareholders). Furthermore, the free circulation of privatization certificates was prohibited. Illegal forms of circulation have contributed to the enlargement of the unofficial sector of the economy (Paskhaver, 2000). Finally, overall bureaucratization of the mass privatization process and lack of transparency also blocked successful reforms.

The goals of the next stage of privatization (cash sales or "privatization for money"), as declared in the State Privatization Program for $1999^{7}$, were also quite contradictory. On the one hand, the State Property Fund of Ukraine (SPFU) should follow a policy of case-by-case privatization, i.e. an individual approach to each enterprise's privatization plan. In other words, when choosing the method of privatization and determining the price of an object, the SPFU should take into account regional and sectoral peculiarities of the enterprise in question, market conditions in which it operates, its financial standing, etc. At the same time, the Program declared the generation of additional income for the state budget as one of the main purposes for selling state enterprises.

Volatility of the general political situation additionally hinders this privatization progress. Since the start of privatization, the government changed seven times while the composition of the Parliament - the Verkhovna Rada - changed three times. After the parliament elections

\footnotetext{
${ }^{6}$ According to the survey of Institute of Reform and London Business School, insiders (employees, former employees, and managers) still own 55\% of statutory funds of Ukrainian joint-stock companies, while outsiders own 35\%. The remaining 10\% belong to the state (Ukrainska Investytsiyna Gazeta, September, 13, 2000).

${ }^{7}$ Verkhovna Rada. The State Privatization Program for 1999. No. 209/99, February, 24, 1999.
} 
of 1994, when communists won a considerable number of seats in the Verkhovna Rada, the privatization process slowed down significantly. A moratorium on privatization was imposed starting from July 1994 and lasting until May 1995. Initial plans to privatize about 30,000 enterprises in 1994 were fulfilled by only a quarter (Yekhanurov, 2000). In addition, the Parliament issued a list of enterprises prohibited from privatization (and the number of enterprises in this list constantly grew $)^{8}$. The process of selection of these enterprises was non-transparent and initiated primarily by the branch ministries which had these enterprises under jurisdiction. Besides, managers of enterprises often resisted privatization, because staying a state-owned enterprise offered a lot of privileges and benefits: fixed level of wages, stable employment, soft-budget constraints and state orders providing stable demand on output.

Furthermore, an additional list of "strategic enterprises" was set up ${ }^{9}$. Enterprises in this group are monopolists (or hold at least $35 \%$ of their product market ${ }^{10}$ ). Since 1994, legislation concerning the status of these entities was changed several times. Nowadays they are subject to privatization, but the state retains either a blocking minority (>25\%) or a controlling share ( $>50 \%$ ) in these enterprises. In the year 2000, the Ukrainian state still held substantial ownership shares in more than 2,500 joint-stock companies (Chechetov, 2000). ${ }^{11}$

\footnotetext{
${ }^{8}$ Resolution of Verkhovna Rada “List of Enterprises Prohibited from Privatization”. No. 847-XIV, July, 7, 1999. Earlier versions: No. 334a/95, May, 1995; No. 542-96, November, 96; No. 203-98, March 98.

9 Resolution of Verkhovna Rada "List of Enterprises that Have Strategic Importance for the Economy and State Security”. No. 1346, August, 29, 2000. Earlier versions: No. 911, August, 21, 1997; No. 1151, July, 27, 1998; No. 801, May, 10, 1999; No. 1157, June, 29, 1999; No. 317, February, 16, 2000.

${ }^{10}$ Antimonopoly Committee Instruction “On Criteria for Defining an Enterprises as a Monopolist”, No. 1-p, March, $10,1994$.

${ }^{11}$ In 1116 JSCs it holds less than 25\% of shares, in 1012 enterprises the state owns between 25\% and 50\% of shares, in 186 - 50\%-75\%, in $235-75 \%-100 \%$.
} 
Ukraine still has a relatively high level of state interference in the economy. Despite the proclaimed statements about privatizing the economy (State Privatization Programs ${ }^{12}$ ), the Ukrainian government, in fact, does not move quickly with effective reforms. In summary, we can outline the following major features of the Ukrainian privatization process so far. Mass privatization resulted in a widely dispersed ownership, which negatively influenced quality of monitoring, and consequently, incentives of managers. Preferential buy-outs by workers' collectives led to insider-dominated ownership. The state still owns large stakes in partially privatized enterprises. The whole privatization process can be characterized as non-transparent and bureaucratized.

Information on decomposition of Ukraine's industrial output, employment and number of enterprises by ownership type is given in Table 1 in the appendix. There are four different types of ownership: state-owned enterprises, collectively-owned companies, private firms, and other forms of ownership. The first group, state-owned enterprises, mainly comprises those enterprises which are prohibited from privatization according to Ukrainian legislation. Their exclusion from the sample should not distort the results since our aim is to analyze privatization effects. Private firms are mostly de-novo created private entities, and are also excluded from our sample. The only group which is of interest to us is that of collectively-owned companies. It consists mainly of joint-stock companies (JSC) — a group of which our sample is representative. JSCs may be separated into two categories: privatized companies, and stateowned enterprises which were incorporated but not privatized (SOE). Both categories are represented in the sample. This sample structure allows us to compare the performance of privatized and state-owned enterprises, and analyze the impact of privatization on enterprise performance.

\footnotetext{
${ }^{12}$ Such Privatization Programs were adopted for following periods: 1992, 1994, 1997, 1999, 2000-2002. In 1998 such Program were rejected by the Parliament.
} 


\section{The Data}

The empirical analysis is based on a sample of 466 Ukrainian industrial open joint-stock companies. Annual reports of enterprises for the period of 1997-1999 include balance sheets, income statements, and information on ownership structure and number of employees. Data for estimation came from two sources. The first part of it, namely annual reports of enterprises for 1997 - 1998, is taken from the database provided by the Institute for Economic Research and Policy Consulting (IERPC). This dataset includes 1694 firms. The second part (namely, reports for 1999) comes from reports of the Securities and Stock Market State Commission (SSMSC) ${ }^{13}$. While more than five thousand enterprise reports are available, our sample consists only of industrial enterprises which provided their annual reports for all three years. The total number of observations in the panel is 1360 . The decomposition of the sample by industries and ownership types is presented in Table 2 in the appendix.

Our sample may be subject to some selection bias for the following reasons. Firstly, only open joint-stock companies are required to make their annual reports publicly available. Data on closed JSCs and non-incorporated state-owned enterprises are inaccessible. Furthermore, the fact that some enterprises have been providing their reports only for one or two years (and therefore, are excluded from the sample) may lead to additional distortions. Therefore, the results of this study should be taken with some caution; they should not necessarily be generalized to apply to the whole set of Ukrainian enterprises.

The sample only includes state-owned, partially privatized, and fully privatized industrial enterprises. De-novo created private firms are excluded from the sample in order to capture

\footnotetext{
${ }^{13}$ http://www.ssmsc.gov.ua.
} 
the particular effects of privatization on the activity of previously existing enterprises. Privatized enterprises in the sample (in which the state owns less than $50 \%$ shares) amount to 348 enterprises in 1997, 359 in 1998 and 396 in 1999 (74.68\%, 77.04\%, and 84.98\% of the total number of firms in the sample, respectively).

We use three measures of performance - sales, labor productivity and profitability. Sales is net sales, measured in thousands of UAH, and deflated by the producer price index ${ }^{14}$. Our main measure, labor productivity $P R O D$, is net sales per employee. Our labor productivity measure is commonly used in similar empirical research. ${ }^{15}$ Lastly, the Profit variable measures profitability as the ratio of profit net of taxes (thousands of UAH) to net sales (both deflated by the producer price index).

Table 3 in the appendix presents a list of variables and their definitions, while Tables 4 and 5 present their descriptive statistics and their correlations respectively. As independent variables we used the regressors listed below. All monetary variables are in thousands of UAH and deflated by the producer price index.

$L A B$ represents the number of employees. $C A P$ is capital used in production.

The STATE variable represents the percentage of shares which belong to the state. The dummy variable $S O E$ is set to one for firms where the state owns more than 50 percent of the joint stock.

$D E B T$, the debt to assets ratio or leverage, is included in the regression in order to capture some internal sources of performance variation. A high debt to assets ratios may indicate that a firm is successful in attracting external funding; since these funds may be invested in

\footnotetext{
${ }^{14}$ Source: Ukrainian Economic Trends, UEPLAC, January 2001.

${ }^{15}$ The logic behind this is intuitive — privatized enterprises use labor more efficiently, and thus have higher rates of productivity growth (Bevan, et. al., 1999).
} 
profitable new projects, leverage may have positive influence on performance. On the other hand, over-leverage of an enterprise may lead to liquidity problems or to incentives to undertake too risky projects. So the net impact on firm's productivity and profitability may be ambiguous.

The COMP variable is calculated as a weighted average of regional and national industry concentration indices. The indices are Hirschman-Herfindahl concentration ratios using output data provided by Derzhkomstat, the Statistical Committee of Ukraine ${ }^{16}$. Comp is used in order to control for the degree of market concentration.

The variable YEAR represents the number of years since privatization. We consider an enterprise as privatized if more than $50 \%$ of its shares belong to private owners. Therefore, even if the privatization process could have begun earlier, YEAR is equal to one in the next year after the state sold more than $50 \%$ of shares. For enterprises which are not privatized YEAR takes a value of zero.

The WAGE variable contains payroll divided by number of employees. Finally the tax arrears to assets ration is captured by the $T A$ variable.

\section{Modelling and Results}

As is common in the literature ${ }^{17}$, we assume that each enterprise in our sample has a production function of the Cobb-Douglas type and that everything produced is sold in the same period. Hence, using the variable definitions from Section 3 above, we receive:

$$
\operatorname{SALES}_{i}(C A P, L A B, A)=C A P_{i}^{\alpha} L A B_{i}^{\beta} A_{i},
$$

\footnotetext{
${ }^{16}$ A similar index was used by Brown and Earle (2001).

${ }_{17}$ See, e.g., Weiss and Nikitin (1998), Pivovarsky (2003).
} 
for firm $i(i=1, \ldots, 466)$, where the variable $A_{i}$ captures all other factors specific to firm $i$ and $\alpha+\beta \leq 1 ; \alpha>0 ; \beta>0$. Growth in net sales can then be estimated as:

$\ln \left(\right.$ Sales $\left._{i}\right)=\alpha \ln C A P_{i}+\beta \ln L A B_{i}+\ln A_{i}$.

And as our main measure of performance we receive growth in net sales per employee:

$$
\ln \left(P R O D_{i}\right)=\ln \left(\frac{\text { Sales }_{i}}{L A B_{i}}\right)=\alpha \ln C A P_{i}+(\beta-1) \ln L A B_{i}+\ln A_{i}
$$

In equation (3), the coefficient of the $\ln (L A B)$ variable should have a negative sign and the coefficient of the $\ln (C A P)$ variable should have positive sign. The variable $\ln \left(A_{i}\right)$ in this case incorporates all other factors that influence the performance of enterprises as described in Section 3 above. Finally, the fixed-effects productivity equation to be estimated may take the following form:

$$
\begin{aligned}
& \ln \left(P R O D_{i t}\right)=\alpha_{i}+\beta_{1} \ln \left(L A B_{i t}\right)+\beta_{2}\left(C A P_{i t}\right)+\beta_{3} S O E_{i t}+\beta_{4} S_{T A T E}+\beta_{5} D E B T_{i t}+\beta_{6} C O M P_{i t}+ \\
& \beta_{7} Y_{E A R_{i t}}+\beta_{8} W \mathrm{WGE}_{i t}+\beta_{9} T A_{t t}+\gamma_{t}+u_{i t}
\end{aligned}
$$

for firm $i(i=1, \ldots, 466)$, in year $t(t=1997,1998,1999)$.

Table (6) in the appendix presents six different model specifications. Models (1) to (4) use $P R O D$ as dependent variable, while Model (5) uses SALES and Model (6) is regressed on PROFIT.

Among the productivity estimations, Model (1) is an OLS pooled regression equation, the models (2) and (3) are with fixed effects, and Model (4) is a random-effect specification. In all four specifications, the parameter estimates for labor $(L A B)$ are negative as expected.

All six models exhibit significant positive effects of the percentage of state ownership, significant negative effects of majority state ownership, and significant negative effects of the 
number of years since privatization. Hence we conclude that the effects of privatization on sales, productivity and profitability may be qualitatively the same.

As expected, majority state ownership (SOE) indicates significantly worse performance. Hence privatization, even if only incomplete, increases performance if it leads to majority private ownership. Although private firms perform better than state-owned firms, performance seems to increase with the percentage of state-ownership (STATE or STATESQ). This probably indicates that formerly state-owned privatized firms continue to derive some benefits from state ties. The negative sign for the effect of number of years since privatization (YEAR) may indicate that privatization benefits decrease over time.

Within our sample, privatization effects seem robust with respect to the performance measure chosen. They also seem to be robust with respect to different estimation methods and model specifications.

\section{Conclusions}

Analyzing a three-year panel of 466 Ukrainian joint-stock companies, we conclude that privatization may positively influence firm performance - sales, labor productivity, and profitability - of formerly state-owned firms if resulting majority control is in private hands but the state retains some minority ownership.

These results are consistent with earlier findings on Ukraine. Brown and Earle (2004), using long panel data for the majority of initially state-owned manufacturing firms, find positive effects of privatization on multi-factor productivity. Pivovarsky (2003), using a smaller sample of 376 firms, also finds evidence for negative effects of majority state ownership on labor productivity. 
Pivovarsky also finds that only concentrated foreign private ownerships leads to increased firm performance, while ownership by Ukrainian investment funds and holding companies does not have such positive effects. While this is not in contradiction to our findings, it suggests that additional research on the differential effects of private ownership by foreign entities versus by domestic ones will be helpful.

We also find that positive privatization effects might get smaller over time for our firm panel. However, Brown and Earle (2004) come to the conclusion that privatization effects on productivity in Ukrainian manufacturing rise over time. ${ }^{18}$ Additional research using an extended data set - specifically more time-periods in the panel - will be necessary to clarify this result.

\section{Literature}

Akimova, Irina, and Gerhard Schwödiauer (2000). "Restructuring Ukrainian Enterprises After Privatization: Does Ownership Matter?” Atlantic Economic Journal, 28(1), 48-59

Antimonopoly Committee of Ukraine (1994). Instruction "On Criteria for Defining an Enterprise as a Monopolist”, March, 10, 1994.

Bevan, A. Alan, Estrin, Saul, and Mark E. Schaffer (1999). "Determinants of Enterprise Performance during Transition”. CERT Discussion Paper No. 99/03

Black, Bernard, Reinier Kraakman and Anna Tarassova (2000). "Russian Privatization and Corporate Governance: What Went Wrong?” Stanford Law Review, 52,1731-1808.

Brown, David J., and John S. Earle (2004). “Does Privatization Raise Productivity: Evidence from Comprehensive Panel Data on Manufacturing Firms in Hungary, Romania, Russia and Ukraine”. CEPR Discussion Paper No. 4791.

Brown, David J., and John S. Earle (2001). "Privatization, Competition, and Reform Strategies: Theory and Evidence from Russian Enterprise Panel Data”. Presented at IZAEERC Workshop, Kyiv, April 9, 2001.

\footnotetext{
${ }^{18}$ For a smaller data set, this is also supported by Grygorenko (2001).
} 
Chechetov, Myhailo (2000). “Budget Revenues or Effective Management?” Mirror Weekly, June11, 2000. [In Ukrainian]

Claessens, Stijn and Simeon Djankov (1999). “Ownership Concentration and Corporate Performance in the Czech Republic”. CEPR Discussion Paper No. 2145

Claessens, Stijn and Simeon Djankov (1998). "Politicians and Firms in Seven Central and Eastern European Countries”. World Bank Policy Research Working Paper 1954.

Derzhkomstat (2000). Main Performance Indicators of Enterprises of Some Branches of the Economy of Ukraine in 1999. Statistics Bulletin.

Djankov, Simeon and Peter Murrel (2002). "Enterprise Restructuring in Transition: An A Quantitative Survey”. Journal of Economic Literature, 60, 739-792.

Djankov, Simeon and Peter Murrel (2000). The Determinants of Enterprise Restructuring in Transition: An Assessment of the Evidence. The World Bank, Washington, D.C.

Earle, John S. and Saul Estrin (2003). “Privatization, Competition, and Budget Constraints: Disciplining Enterprises in Russia”. Economics of Planning, 36, 1-22.

EBRD (1999). Transition Report.

Frydman, Roman, Cheryl Gray, Marek Hessel and Andrzej Rapaczynski (1999). When Does Privatization Work? The Impact of Private Ownership on Corporate Performance in the Transition Economies. Fifth Nobel Symposium in Economics (Session 5). September 1012, 1999. Stockholm, Sweden.

Grygorenko, Galyna (2001). Do Privatized Enterprises Perform Better Than State-Owned Ones in Ukraine? Master's Thesis, EERC, Kiev, Ukraine.

IMF (1999). Ukraine - Recent Economic Developments. IMF Staff Country Report.

Kay, John A. and D. J. Thomso. (1986). "Privatization: A Policy Search for Rationale”. Economic Journal, 96(381).

Megginson, William L. (2005). The Financial Economics of Privatization. Oxford University Press.

Megginson, William L., and Jeffrey M. Netter (2001). "From State to Market: A Survey of Empirical Studies on Privatization”. Journal of Economic Literature, 39(2), 321-389.

Megginson, William L., Nash R.C., and M. van Randenborgh (1994). “The Financial and Operating Performance of Newly Privatized Firms: An Empirical Analysis”. The Journal of Finance, 49(2), 403-452. 
Nellis, John (1999). “Time to Rethink Privatization in Transition Economies?” Discussion Paper No. 38. International Finance Corporation.

Paskhaver, Alexander (2000). "Privatization in Ukraine: Preliminary Conclusions”. The Ukrainian Economic Monitor. No.1 (44).

Pivovarsky, A. (2003). Ownership Concentration and Performance in Ukraine's Privatized Enterprises. IMF Staff Papers, 50(1).

Presidential Decree “On Expedient Measures to Accelerate Privatization in Ukraine”. No. 1626, December, 29, 1999.

Roland, Gerard (2000). Transition and Economics. The MIT Press.

Sheshinski, Eytan, and Luis Felipe López-Calva (1999). "Privatization and its Benefits: Theory and Evidence”. HIID Development Discussion Paper no. 698.

UEPLAC (2001). Ukrainian Economic Trends. January 2001.

Verkhovna Rada (1992). The Law of Ukraine “On Privatization of State Property”, No. 2163-12, March, 1992.

Verkhovna Rada (1992). The Law of Ukraine “On Privatization Certificates”, No. 2713-12, March, 1992.

Verkhovna Rada (1992). State Privatization Programs. No. 2545-XII, July, 7, 1992; No. 209/99, February, 24, 1999; No. 1723-14, May, 18, 2000.

Verkhovna Rada (1999). Resolution “List of Enterprises Prohibited from Privatization”. No. 847-XIV, July, 7, 1999.

Verkhovna Rada (2000). Resolution "List of Enterprises that Have Strategic Importance for the Economy and State Security”. No. 1346, August, 29, 2000.

Vickers, John, and George Yarrow (1991). “Economic Perspectives on Privatization”. The Journal of Economic Perspectives. 5, pp. 111-132.

Weiss, A. and G. Nikitin (1998). "Performance of Czech Companies by Ownership Structure”, William Davidson Institute Working paper No. 186, University of Michigan.

World Bank (1999). Ukraine. Restoring Growth with Equity: A Participatory Country Economic Memorandum. World Bank, Washington, D.C.

Yekhanurov, Yuri I (2000). “The Progress of Privatization”. In Åslund, Anders and Georges de Ménil (eds.). Economic Reform in Ukraine: The Unfinished Agenda. M. E. Sharpe, New York, NY. 


\section{Appendix}

Table 1. Relative Importance of Different Ownership Types.

\begin{tabular}{|c|c|c|c|c|c|}
\hline & $\begin{array}{l}\text { Ukraine } \\
\text { (total) }\end{array}$ & \multicolumn{4}{|c|}{ Including: } \\
\hline & $\begin{array}{c}\text { State-owned } \\
\text { enterprises }\end{array}$ & $\begin{array}{c}\text { Collectively } \\
\text { owned } \\
\text { companies }\end{array}$ & Private firms & $\begin{array}{c}\text { Other forms of } \\
\text { ownership }\end{array}$ \\
\hline $\begin{array}{c}\text { Number of } \\
\text { enterprises }\end{array}$ & 10,527 & 1,495 & 8,837 & 145 & 50 \\
\hline$\%$ & $100 \%$ & $14.2 \%$ & $83.9 \%$ & $1.4 \%$ & $0.5 \%$ \\
\hline $\begin{array}{c}\text { Employment } \\
\text { (workers) }\end{array}$ & $4,622,144$ & $1,440,070$ & $3,160,892$ & 12,460 & 8,722 \\
\hline$\%$ & $100 \%$ & $31.1 \%$ & $68.4 \%$ & $0.03 \%$ & $0.02 \%$ \\
\hline $\begin{array}{c}\text { Output } \\
\text { million) }\end{array}$ & $103,783.6$ & $31,547.9$ & $71,435.4$ & 274.7 & 525.6 \\
\hline$\%$ & $100 \%$ & $30.4 \%$ & $68.8 \%$ & $0.3 \%$ & $0.5 \%$ \\
\hline
\end{tabular}

Source: Derzhkomstat. 2000. Statistics bulletin 
Table 2. Decomposition of the sample by sectors and ownership type

\begin{tabular}{|c|c|c|c|c|c|c|c|c|c|c|}
\hline \multirow[t]{2}{*}{$\begin{array}{l}\text { Industries / } \\
\text { Ownership type }\end{array}$} & \multicolumn{3}{|l|}{ SOE } & \multicolumn{3}{|c|}{$\begin{array}{l}\text { PARTIALLY } \\
\text { PRIVATIZED }\end{array}$} & \multicolumn{3}{|c|}{$\begin{array}{l}\text { FULLY } \\
\text { PRIVATIZED }\end{array}$} & \multirow{2}{*}{$\begin{array}{l}\text { Total } \\
\text { number } \\
\text { of firms }\end{array}$} \\
\hline & 1997 & 1998 & 1999 & 1997 & 1998 & 1999 & 1997 & 1998 & 1999 & \\
\hline Fuel industry & 7 & 7 & 5 & 2 & 2 & 3 & 0 & 0 & 1 & 9 \\
\hline Power industry & 16 & 16 & 14 & 5 & 5 & 7 & 3 & 3 & 3 & 24 \\
\hline Ferrous metallurgy & 16 & 14 & 12 & 6 & 6 & 7 & 13 & 15 & 16 & 35 \\
\hline $\begin{array}{l}\text { Non-ferrous } \\
\text { metallurgy }\end{array}$ & 1 & 1 & 1 & 1 & 1 & 1 & 2 & 2 & 2 & 4 \\
\hline $\begin{array}{l}\text { Chemical and } \\
\text { petrol-chemical } \\
\text { industry }\end{array}$ & 9 & 9 & 8 & 4 & 4 & 3 & 16 & 16 & 18 & 29 \\
\hline Machine-building & 31 & 29 & 18 & 29 & 30 & 29 & 71 & 72 & 84 & 131 \\
\hline $\begin{array}{l}\text { Wood, Pulp and } \\
\text { Paper industries }\end{array}$ & 4 & 4 & 1 & 2 & 2 & 3 & 10 & 10 & 12 & 16 \\
\hline $\begin{array}{l}\text { Construction } \\
\text { materials industry }\end{array}$ & 10 & 9 & 6 & 4 & 5 & 3 & 42 & 42 & 47 & 56 \\
\hline Light industry & 1 & 1 & 0 & 4 & 4 & 3 & 15 & 15 & 17 & 20 \\
\hline Food industry & 23 & 17 & 5 & 24 & 27 & 26 & 85 & 88 & 101 & 132 \\
\hline Other & 0 & 0 & 0 & 3 & 3 & 4 & 7 & 7 & 6 & 10 \\
\hline Total & 118 & 107 & 70 & 84 & 89 & 89 & 264 & 270 & 307 & 466 \\
\hline
\end{tabular}


Table 3. List of Variables.

\begin{tabular}{|c|c|}
\hline Variable & Definition \\
\hline PROFIT & profit net of taxes divided by net sales $\left.{ }^{*}\right)$ \\
\hline SALES & net sales (UAH thousand) ${ }^{*}$ \\
\hline$\overline{P R O D}$ & $\begin{array}{l}\text { net sales divided by number of employees (UAH } \\
\text { thousand) }\end{array}$ \\
\hline$L A B$ & labor used (number of employees) \\
\hline CAP & capital used (UAH thousand) $\left.^{*}\right)$ \\
\hline DEBT & debt to asset ratio ${ }^{*}$ \\
\hline SOE & $\begin{array}{l}\text { Dummy variable equals } 1 \text { for joint-stock enterprises with } \\
\text { more than } 50 \% \text { state holdings }\end{array}$ \\
\hline STATE & ownership variable (percentage of shares held by the state) \\
\hline STATESQ & The STATE variable squared \\
\hline COMP & $\begin{array}{l}\text { competition variable (a weighted Hirschman-Herfindahl } \\
\text { concentration ratio) }^{* *} \text { ) }\end{array}$ \\
\hline YEAR & $\begin{array}{l}\text { years since privatization (equal to zero if an enterprise is } \\
\text { not privatized) }\end{array}$ \\
\hline WAGE & payroll divided by number of employees (UAH thousand) ${ }^{*}$ \\
\hline TA & tax arrears to asset ratio ${ }^{*}$ \\
\hline
\end{tabular}

*) All monetary variables deflated by producer price index.

**) $\mathrm{COMP}_{j t}=$ OShare $_{j t} \times H H I_{j t}^{R}+\left(1-\right.$ OShare $\left._{j t}\right) \times H H I_{j t}^{N}$, where $j$ is an index for industries; $t$ is a time index ( $t=1997 . .1999)$;

OShare $_{j t}$ is a proportion of oblasts, in which there is at least one enterprise of the industry $j$;

$H H I{ }_{j t}^{R}$ is the concentration ratio at the regional level (oblasts level);

$H H I_{j t}^{N}$ is the concentration ratio at the national level (country level). 
Table 4. Descriptive statistics

\begin{tabular}{|c|c|c|c|c|c|c|}
\hline & PROFIT & SALES & PROD & CAP & LAB & STATE \\
\hline Mean & -0.229138 & 49110.56 & 20.49824 & 70430.3 & 1603.778 & 21.69081 \\
\hline Median & 0.01016 & 4137.504 & 10.27576 & 7491.85 & 424 & 0 \\
\hline Maximum & 15.34078 & 1964484 & 1187.216 & 1936739 & 26059 & 100 \\
\hline Minimum & -28.33333 & 1.013 & 0.011644 & 0 & 4 & 0 \\
\hline Std. Dev. & 1.571591 & 166502.4 & 54.45853 & 188365.7 & 3354.456 & 32.847 \\
\hline Skewness & -9.184084 & 6.429104 & 14.90479 & 5.140975 & 4.468877 & 1.300802 \\
\hline Kurtosis & 147.3142 & 52.78046 & 282.5369 & 35.94001 & 26.84085 & 3.257819 \\
\hline Jarque-Bera & 1199293 & 149794.3 & 4478337 & 67476.57 & 36735.28 & 387.3063 \\
\hline Probability & 0 & 0 & 0 & 0 & 0 & 0 \\
\hline Sum & -311.6271 & 66790360 & 27877.61 & 95785206 & 2181138 & 29499.5 \\
\hline Sum Sq. Dev. & 3356.594 & $3.77 \mathrm{E}+13$ & 4030430 & $4.82 \mathrm{E}+13$ & $1.53 \mathrm{E}+10$ & 1466260 \\
\hline Observations & 1360 & 1360 & 1360 & 1360 & 1360 & 1360 \\
\hline Cross sections & 466 & 466 & 466 & 466 & 466 & 466 \\
\hline
\end{tabular}

\begin{tabular}{|c|c|c|c|c|c|}
\hline & SOE & DEBT & COMP & YEAR & TA \\
\hline Mean & 0.208088 & 0.251465 & 0.396105 & 2.076471 & 0.002759 \\
\hline Median & 0 & 0.183478 & 0.380105 & 2 & 0 \\
\hline Maximum & 1 & 1.466993 & 1 & 6 & 0.154358 \\
\hline Minimum & 0 & 0.00276 & 0 & 0 & 0 \\
\hline Std. Dev. & 0.40609 & 0.21437 & 0.236491 & 1.443069 & 0.012798 \\
\hline Skewness & 1.4382 & 1.656602 & 0.429315 & 0.208734 & 7.830923 \\
\hline Kurtosis & 3.068421 & 6.385546 & 2.384537 & 2.244488 & 75.19433 \\
\hline Jarque-Bera & 469.1073 & 1305.216 & 63.24225 & 42.22103 & 309247.8 \\
\hline Probability & 0 & 0 & 0 & 0 & 0 \\
\hline Sum & 283 & 351.0445 & 538.7023 & 2824 & 3.751944 \\
\hline Sum Sq. Dev. & 224.111 & 64.10667 & 76.00597 & 2830.047 & 0.222593 \\
\hline Observations & 1360 & 1360 & 1360 & 1360 & 1360 \\
\hline Cross sections & 466 & 466 & 466 & 466 & 466 \\
\hline
\end{tabular}


Table 5. Correlation coefficients

\begin{tabular}{|l|c|c|l|l|l|l|l|l|l|l|l|l|}
\hline & PROFIT SALES & PROD & CAP & LAB & STATE & SOE & DEBT & COMP & YEAR & TA & WAGE \\
\hline PROFIT & 1.0000 & & & & & & & & & & & \\
\hline SALES & 0.0512 & 1.0000 & & & & & & & & & & \\
\hline PROD & 0.0633 & 0.2648 & 1.0000 & & & & & & & & & \\
\hline CAP & 0.0493 & 0.8112 & 0.1332 & 1.0000 & & & & & & & & \\
\hline LAB & 0.0600 & 0.7489 & 0.0939 & 0.8908 & 1.0000 & & & & & & & \\
\hline STATE & 0.0046 & 0.2665 & 0.0460 & 0.3191 & 0.2887 & 1.0000 & & & & & & \\
\hline SOE & -0.0064 & 0.2612 & 0.0540 & 0.3081 & 0.2755 & 0.9066 & 1.0000 & & & & & \\
\hline DEBT & -0.0118 & 0.1883 & 0.2267 & 0.1415 & 0.1490 & -0.0130 & -0.0173 & 1.0000 & & & & \\
\hline COMP & -0.0005 & 0.0016 & 0.0152 & 0.0060 & 0.0331 & 0.0458 & 0.0324 & -0.1168 & 1.0000 & & & \\
\hline YEAR & -0.0667 & -0.0901 & -0.0654 & -0.0437 & 0.0249 & -0.1639 & -0.1409 & 0.0132 & 0.0850 & 1.0000 & & \\
\hline TA & 0.0053 & 0.0234 & -0.0317 & 0.0752 & 0.0789 & 0.1318 & 0.1306 & 0.1018 & -0.0574 & -0.0196 & 1.0000 & \\
\hline WAGE & 0.1231 & 0.2213 & 0.4207 & 0.1931 & 0.1639 & 0.0466 & 0.0402 & 0.1512 & -0.0043 & -0.0582 & -0.0453 & 1.0000 \\
\hline
\end{tabular}


Table 6. Estimation results

\begin{tabular}{|c|c|c|c|c|c|c|}
\hline & (1) OLS & (2) FE & (3) FE & (4) RE & (5) FE & (6) FE \\
\hline $\begin{array}{l}\text { Dependent } \\
\text { Variable }\end{array}$ & $\begin{array}{c}\text { PROD } \\
\text { (Log) }\end{array}$ & $\begin{array}{c}\text { PROD } \\
\text { (Log) }\end{array}$ & $\begin{array}{c}\text { PROD } \\
\text { (Log) }\end{array}$ & $\begin{array}{c}\text { PROD } \\
\text { (Log) }\end{array}$ & $\begin{array}{c}\text { SALES } \\
\text { (Log) }\end{array}$ & PROFIT \\
\hline LAB (Log) & $\begin{array}{c}-0.1596 * * \\
(0.0670)\end{array}$ & $\begin{array}{c}-0.5770 * * * \\
(0.0623)\end{array}$ & $\begin{array}{c}-0.2309 \\
(0.1820)\end{array}$ & $\begin{array}{c}-0.1379 \\
(0.1347)\end{array}$ & $\begin{array}{c}0.4230 * * * \\
(0.0623)\end{array}$ & $\begin{array}{l}0.8419 * \\
(0.5947\end{array}$ \\
\hline CAP (Log) & $\begin{array}{c}0.2552 * * * \\
(0.0042)\end{array}$ & $\begin{array}{c}0.1278 * * * \\
(0.0285)\end{array}$ & $\begin{array}{c}0.1361 * * * \\
(0.0218)\end{array}$ & $\begin{array}{c}0.1975 * * \\
(0.0897)\end{array}$ & $\begin{array}{c}0.1278 * * * \\
(0.0285)\end{array}$ & $\begin{array}{c}0.1084 * * \\
(0.0482)\end{array}$ \\
\hline STATE & $\begin{array}{c}0.0042 * * * \\
(0.0003)\end{array}$ & $\begin{array}{c}0.0034^{* * *} \\
(0.0003)\end{array}$ & & $\begin{array}{l}0.0022^{* *} \\
(0.0009)\end{array}$ & $\begin{array}{c}0.0034 * * * \\
(0.0003)\end{array}$ & $\begin{array}{c}0.0019 * * * \\
(0.0003)\end{array}$ \\
\hline STATESQ & & & $\begin{array}{c}0.00005^{* * *} * \\
(0.00001)\end{array}$ & & & \\
\hline SOE & $\begin{array}{c}-0.2868 * * * \\
(0.0485)\end{array}$ & $\begin{array}{c}-0.2360 * * * \\
(0.0292)\end{array}$ & $\begin{array}{c}-0.3215 * * * \\
(0.0755)\end{array}$ & $\begin{array}{c}-0.0982 \\
(0.1550) \\
\end{array}$ & $\begin{array}{c}-0.2360 * * * \\
(0.0292)\end{array}$ & $\begin{array}{c}-0.0836^{*} \\
(0.0552) \\
\end{array}$ \\
\hline DEBT & $\begin{array}{c}0.5172 * * * \\
(0.1414)\end{array}$ & $\begin{array}{c}0.5854 * * * \\
(0.0676) \\
\end{array}$ & $\begin{array}{c}0.4782 * * * \\
(0.0920) \\
\end{array}$ & $\begin{array}{c}0.8562 * * * \\
(0.1237) \\
\end{array}$ & $\begin{array}{c}0.5854 * * * \\
(0.0676) \\
\end{array}$ & $\begin{array}{c}-0.6146^{* * * *} \\
(0.1892)\end{array}$ \\
\hline COMP & $\begin{array}{c}-0.1079 \\
(0.0810)\end{array}$ & $\begin{array}{c}0.4548 * * \\
(0.2392)\end{array}$ & $\begin{array}{c}0.4304^{* *} \\
(0.2311) \\
\end{array}$ & $\begin{array}{c}-0.1288 \\
(0.3298) \\
\end{array}$ & $\begin{array}{c}0.4548 * * \\
(0.2392)\end{array}$ & \\
\hline YEAR & $\begin{array}{c}-0.1517 * * * \\
(0.0333)\end{array}$ & $\begin{array}{c}-0.1267 * * * \\
(0.0242)\end{array}$ & $\begin{array}{c}-0.1215^{* * *} \\
(0.0289)\end{array}$ & $\begin{array}{c}-0.2203 * * * \\
(0.0166)\end{array}$ & $\begin{array}{c}-0.1267 * * * \\
(0.0242)\end{array}$ & \\
\hline WAGE & $\begin{array}{c}0.2052 * * * \\
(0.0254)\end{array}$ & & $\begin{array}{c}0.2196 * * * \\
(0.0661) \\
\end{array}$ & & & $\begin{array}{l}0.1769 * \\
(0.1049) \\
\end{array}$ \\
\hline TA & $\begin{array}{c}2.1466 * * \\
(0.9456) \\
\end{array}$ & & $\begin{array}{c}2.2252^{* * *} \\
(0.5913) \\
\end{array}$ & & & $\begin{array}{c}3.0175^{* * *} \\
(1.0523) \\
\end{array}$ \\
\hline Firm effects & - & $\mathrm{Y}$ & $\mathrm{Y}$ & $\mathrm{Y}$ & $\mathrm{Y}$ & $\mathrm{Y}$ \\
\hline Period effects & - & $\mathrm{Y}$ & $\mathrm{Y}$ & - & $\mathrm{Y}$ & $\mathrm{Y}$ \\
\hline Adj. R-squared & 0.77 & 0.83 & 0.84 & 0.11 & 0.94 & 0.31 \\
\hline S.E. regression & 0.5984 & 0.5431 & 0.5180 & 0.5601 & 0.5431 & 1.2364 \\
\hline Sum sq. residuals & 307.98 & 259.27 & 231.05 & 421.31 & 259.27 & 1316.16 \\
\hline F-statistic & 298.69 & 14.99 & 15.95 & 18.57 & 49.11 & 2.26 \\
\hline Durbin-Watson & 1.84 & 2.21 & 2.34 & 1.46 & 2.21 & 2.39 \\
\hline
\end{tabular}

Note. (i) All equations include a constant; equation (1) includes an AR(1) term; equation (4) includes firm size (employment) dummies. (iii) Heteroscedastic consistent standard errors in brackets. (iv) $* * *$ denotes significant at the $1 \%$, ** at the $7 \%, *$ at the $16 \%$ level. 